\title{
THE GEOCHEMISTRY AND MINERALOGY OF ZIRCONS FROM SRI LANKA
}

\author{
M. S. RUPASINGHE and C. B. DISSANAYAKE
}

\begin{abstract}
RUPASINGHE, M. S. and DISSANAYAKE, C. B., 1987: The geochemistry and mineralogy of zircons from Sri Lanka. Bull. Geol. Soc. Finland 59, Part 1, 3-19.

A total of 51 sediment samples and 40 rock samples from the main gem fields of Sri Lanka have been analysed for their $\mathrm{Zr}$ contents. The results indicated a marked enrichment of $\mathrm{Zr}$ in the sediments as against the probable source rocks. Fortynine zircon separates from the gem-bearing sediments were analysed by electron microprobe and neutron activation for their trace and rare-earth element concentrations. Of the green, yellow, violet and rose zircon varieties studied, the green zircons showed relatively high enrichment in Th, U and Hf. Chondrite-normalized REE plots for five zircon separates revealed markedly similar patterns with HREE enrichments. The similarity of the plots could well indicate a similar source of origin for the zircons. Seven zoned zircons were also studied for their elemental composition. Even though there were periodic changes in the elemental composition within one zone, there were, on an average, no distinct elemental variations from the rim to the core of the zircon grain.
\end{abstract}

Key words: sediments, rocks, zircon, chemical composition, rare earths, Sri Lanka, Ratnapura, Elahera.

M. S. Rupasinghe: University of Mainz, Institut für Edelsteinforschung, Saarstrasse 21, Mainz, West Germany.

C. B. Dissanayake: Department of Geology, University of Peradeniya, Sri Lanka.

\section{Introduction}

Zircon has been studied extensively as an accessory mineral in rocks. Being much used as an indicator of petrogenesis, zircons are studied for their ages, REE concentrations, shapes and colours, as well as concentrations of many trace elements. Numerous attempts have been made to correlate the trace element chemistry of zircons and other accessory minerals with their geological environments (Fleischer and Altschuler 1969; Puchelt and Emmermann 1976; Exley 1980; Murali et al. 1983). Further, zircon is also considered to be a gem mineral and certain varieties are often subjected to detailed physical and chemical investigations.

The gem-bearing sediments of Sri Lanka are well-known throughout the world for their diversity of gemstones, especially varieties of corundum, chrysoberyl, spinel, garnet, tourmaline and topaz. Zircon is ubiquitous in these gem-bearing sediments, and yellow, green, violet and rose varieties are often observed. However, very little work has been done so far on the trace element geochemistry and mineralogy of these zircons from Sri Lanka.

This paper highlights the significant mineralogy, and the trace element concentrations and 


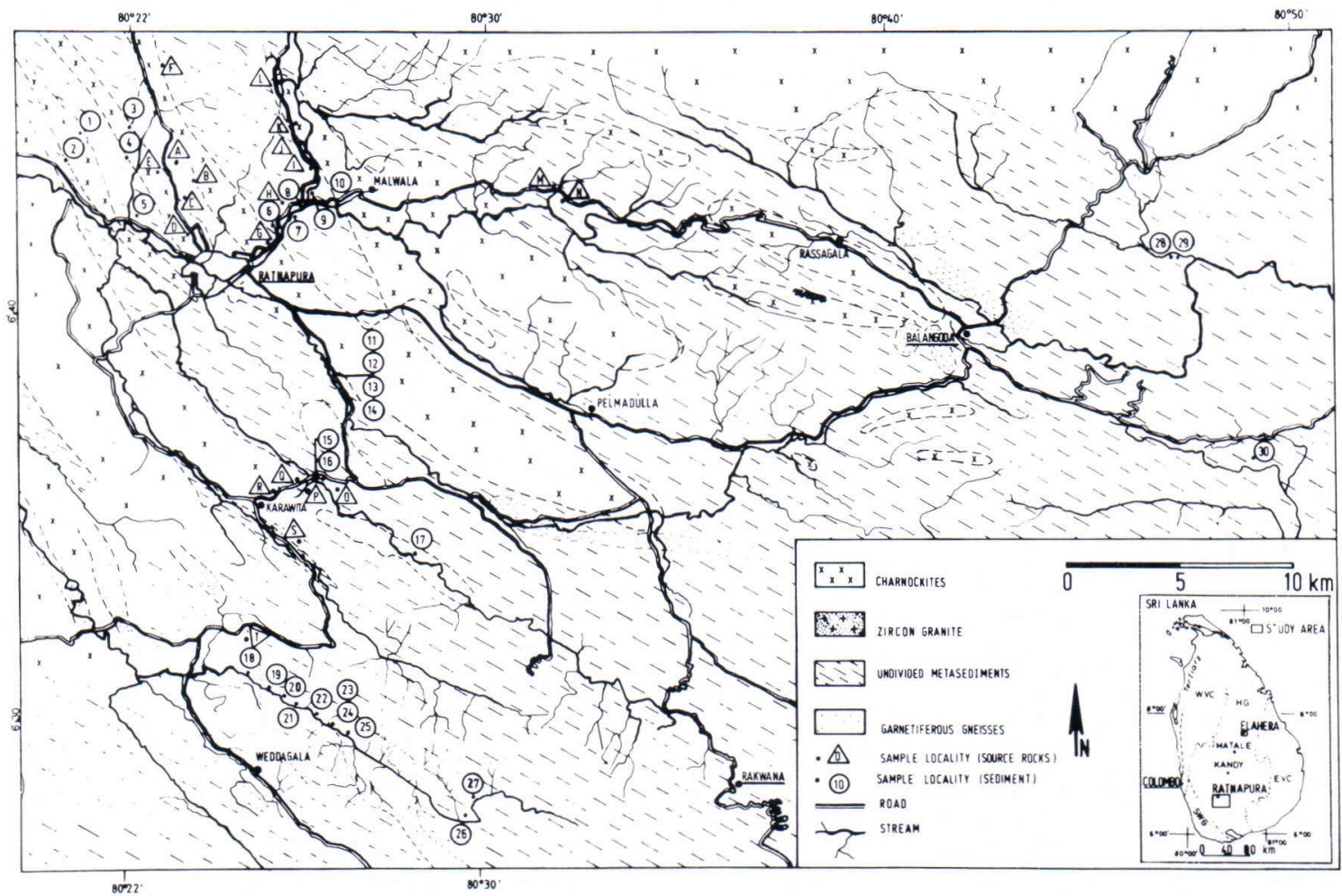

Fig. 1. The geology of the Ratnapura gem field of Sri Lanka showing sampling locations. The inset shows the study areas with respect to the main geological divisions of Sri Lanka.

their variations in the zoned and ordinary zircon minerals from the gem-bearing sediments of Sri Lanka.

\section{Study areas}

Figure 1 (see inset) shows the location of the study areas with respect to the major geological divisions of Sri Lanka. The bulk of the island is composed of Precambrian metamorphic rocks, which are subdivided into the following major divisions (Cooray, 1978):

(a) Highland Group (Pyroxene-granulite facies) consisting of charnockites, quartzites, marbles, garnetiferous gneisses, hornblende gneisses, granulites and pegmatites;

(b) Vijayan Complex (amphibolite-granulite facies) consisting of hornblende biotite gneisses, migmatites and granites; (c) South-West Group (cordierite-granulite facies) composed of cordierite gneisses, wollastonite scapolite rocks and calc gneisses.

Figure 1 illustrates the geology of the Ratnapura, Rakwana and Balangoda areas. Except for scattered patches of alluvium, the areas included in the Ratnapura and Rakwana topographic sheets consist of Precambrian metamorphic rocks of the charnockite-metasedimentary type. The major rock types are charnockites, garnet-sillimanite granulites, amphibolite and perthitebearing garnet-biotite granulitic gneisses, with charnockites and the pelitic garnet-sillimanite granulites being the dominant types. Also of importance are intrusive rocks of the zircon granite type, and vein quartz and pegmatites.

The Ratnapura and Rakwana gem field is an expanse of Pleistocene or sub-recent alluvium containing patches or streaks of gravel of Heavy 


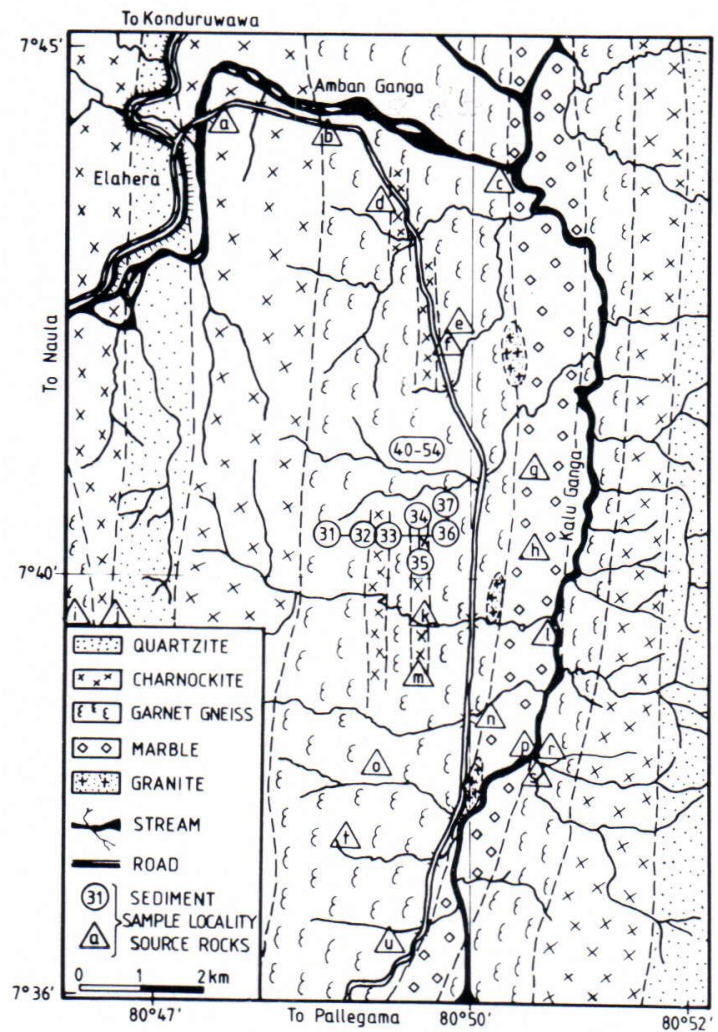

Fig. 2. The geology of the Elahera gem-bearing area showing the sampling locations.

minerals laid down in the beds of streams, in flood plains, in the beds of abandoned tributaries or in talus fans at the foot of the steep slopes of hillsides (Wadia and Fernando 1945). Lenses of layers of gravel deposited during periods of intense flooding carry with them numerous heavy minerals, including gems denuded from an extensive catchment area.

Figure 2 shows the geology of the Elahera gem field in northeastern Sri Lanka, which is characterized by ridge and valley topography in a plunging synclinal structure. Silva (1976) reported the occurrence of granites and pegmatites in the area. The general rock types consist of quartzite, marbles and garnet-sillimanite biotite gneisses with tourmaline and charnockites. Tourmalinization of the garnetiferous gneisses is especially pronounced. The gem-bearing surficial material in the area consists predominantly of laterites but also of sandy gravel.

\section{Sampling and analytical techniques}

Fifty-one sediment samples and 40 fresh rock samples were collected from the localities shown in Fig. 1 and 2. All the sediment samples were extracted from existing gem pits dug into buried river beds in the region. The pay gravel layers, or »Illams» as they are known locally in Sinhalese, are usually composed of rounded or subangular pebbles or boulders of quartz, heavy minerals and gem stones.

Fifteen to 25 buckets of »Illam» were taken from each pit and washed until the clay was removed. The remaining portion, locally termed "Nambuwa», was placed in polythene bags. An average sample weighed from 10 to $15 \mathrm{~kg}$.

Fresh rock samples weighing about $5 \mathrm{~kg}$ were collected from quarries, road cutting and natural outcrops in the area.

In the separation of Zircon from other minerals in the »Nambuwa», the following techniques and instruments were used in addition to visual identification:

\section{- Geiger-Müller counter}

- density measurements

- RI (refractive index) measurements

- X-ray diffractometer.

For the chemical analyses, sediment samples and rock samples were crushed and sieved, carefully avoiding all possible contamination. The $<0.063 \mathrm{~mm}$ size fractions were dissolved in order to analyse them with Inductively Coupled Plasma spectrometry (ICP) using a Bausch-Lomb ARL instrument. The analytical accuracy, checked against standard sediment samples, gave a relative standard deviation of $\pm 5 \%$.

About 50 zircon grains were divided into four different colours, green, yellow, rose and violet. These sets were mounted in brass rings and analysed using a CAMECA CAMEBAX MICROBEAM (Microprobe). At least three points 
Table 1. The contents of $\mathrm{Zr}$ and other elements in the Ratnapura gem-bearing sediments (see Fig. 1 for locations)

a

\begin{tabular}{|c|c|c|c|c|c|c|c|c|c|c|c|c|c|c|c|c|c|c|c|c|c|}
\hline $\begin{array}{l}\text { RATNAPURA } \\
\text { sed. } \\
\text { sample }\end{array}$ & $\mathrm{ppm}$ & $\begin{array}{c}\mathrm{Na}_{2} \mathrm{O} \\
\% \\
\end{array}$ & $\begin{array}{c}\mathrm{K}_{2} \mathrm{O} \\
\% \\
\end{array}$ & $\mathrm{ppm}$ & $\mathrm{ppm}$ & $\mathrm{MgO}$ & $\mathrm{CaO}$ & $\begin{array}{c}\mathrm{Sr} \\
\mathrm{ppm} \\
\end{array}$ & $\mathrm{ppm}$ & $\begin{array}{c}\mathrm{Al}_{2} \mathrm{O}_{3} \\
\% \\
\%\end{array}$ & $\begin{array}{c}\mathrm{Zr} \\
\mathrm{ppm} \\
\end{array}$ & $\begin{array}{c}\mathrm{TiO}_{2} \\
\% \\
\end{array}$ & ppm & $\begin{array}{l}\mathrm{Cr} \\
\mathrm{ppm} \\
\end{array}$ & $\begin{array}{l}\mathrm{Mn} \\
\mathrm{ppm}\end{array}$ & $\begin{array}{c}\mathrm{Fe}_{2} \mathrm{O}_{3} \\
\% \\
\end{array}$ & $\begin{array}{l}\mathrm{Co} \\
\mathrm{ppm} \\
\end{array}$ & $\begin{array}{l}\mathrm{Ni} \\
\mathrm{ppm}\end{array}$ & $\begin{array}{l}\mathrm{Cu} \\
\mathrm{ppm} \\
\end{array}$ & $\begin{array}{l}\mathrm{Zn} \\
\mathrm{ppm} \\
\end{array}$ & $\begin{array}{c}\mathrm{SiO}_{2} \\
\% \\
\end{array}$ \\
\hline 1 & 51 & 0.55 & 2.31 & 112 & 7 & 2.81 & 2.32 & 100 & 370 & 21.92 & 971 & 2.07 & 263 & 319 & 364 & 9.88 & 43 & 337 & 114 & 242 & 43.65 \\
\hline 2 & 36 & 0.38 & 1.94 & 75 & 6 & 0.93 & 1.01 & 85 & 694 & 18.97 & 620 & 2.47 & 194 & 187 & 298 & 8.44 & 35 & 136 & 54 & 215 & n.a. \\
\hline 3 & 29 & 0.54 & 3.54 & 92 & 7 & 0.63 & 0.46 & 141 & 1228 & 20.92 & 707 & 2.25 & 185 & 381 & 1007 & 17.00 & 82 & 182 & 40 & 254 & n.a. \\
\hline 4 & 46 & 0.34 & 2.64 & 258 & 11 & 0.32 & 0.25 & 84 & 811 & 24.90 & 500 & 1.30 & 179 & 305 & 309 & 6.25 & 67 & 119 & 45 & 158 & 54.84 \\
\hline 5 & 64 & 0.32 & 2.12 & 168 & 6 & 0.65 & 0.36 & 76 & 643 & 26.06 & 536 & 1.32 & 264 & 251 & 301 & 6.52 & 43 & 238 & 87 & 263 & 44.48 \\
\hline 6 & 52 & 0.41 & 4.70 & 175 & 7 & 0.44 & 0.23 & 93 & 937 & 23.05 & 298 & 0.39 & 134 & 136 & 264 & 12.60 & 45 & 130 & 54 & 205 & 43.10 \\
\hline 7 & 20 & 0.65 & 1.89 & 75 & 4 & 0.48 & 0.46 & 141 & 540 & 22.22 & 560 & 0.82 & 248 & 363 & 279 & 19.81 & 48 & 172 & 121 & 240 & 43.53 \\
\hline 8 & 23 & 0.11 & 1.73 & 140 & 5 & 0.50 & 0.19 & 80 & 558 & 21.65 & 503 & 1.18 & 203 & 257 & 604 & 13.13 & 62 & 105 & 79 & 185 & 47.44 \\
\hline 9 & 23 & 0.13 & 1.14 & 90 & 13 & 0.84 & 0.07 & 80 & 425 & 35.75 & 226 & 1.25 & 230 & 200 & 291 & 7.35 & 12 & 112 & 49 & 120 & 43.49 \\
\hline 10 & 30 & 0.46 & 2.55 & 84 & 4 & 0.55 & 0.21 & 82 & 522 & 22.26 & 491 & 1.28 & 220 & 168 & 293 & 12.64 & 20 & 140 & 53 & 140 & 42.94 \\
\hline 11 & 26 & 1.02 & 0.86 & 161 & 5 & 1.00 & 0.77 & 79 & 487 & 18.12 & 201 & 0.43 & 210 & 116 & 273 & 14.09 & 52 & 182 & 41 & 342 & 50.81 \\
\hline 12 & 29 & 0.11 & 0.87 & 102 & 8 & 0.21 & 0.40 & 61 & 168 & 27.74 & 446 & 2.05 & 424 & 342 & 308 & 14.83 & 17 & 280 & 57 & 177 & 42.73 \\
\hline 13 & 21 & 0.10 & 0.65 & 34 & 4 & 0.05 & 0.06 & 84 & 192 & 20.41 & 507 & 1.11 & 270 & 158 & 347 & 15.36 & 30 & 107 & 92 & 164 & 50.42 \\
\hline 14 & 33 & 0.09 & 0.29 & 150 & 8 & 0.27 & 0.58 & 100 & 170 & 32.61 & 465 & 1.78 & 363 & 240 & 703 & 18.38 & 28 & 202 & 117 & 205 & 35.86 \\
\hline 15 & 49 & 0.70 & 1.02 & 58 & 7 & 3.52 & 2.42 & 57 & 616 & 17.31 & 385 & 0.51 & 113 & 81 & 3415 & 18.59 & 40 & 191 & 82 & 237 & 42.91 \\
\hline 16 & 64 & 0.45 & 1.29 & 92 & 11 & 3.39 & 2.63 & 150 & 999 & 17.95 & 242 & 0.71 & 130 & 155 & 3833 & 16.59 & 54 & 156 & 100 & 301 & 47.07 \\
\hline 17 & 30 & 0.19 & 0.95 & 126 & 4 & 0.24 & 1.26 & 101 & 667 & 23.58 & 414 & 1.04 & 271 & 333 & 527 & 10.34 & 104 & 179 & 117 & 399 & 48.28 \\
\hline 18 & 49 & 0.24 & 2.24 & 40 & 9 & 0.15 & 0.18 & 84 & 669 & 25.36 & 691 & 2.29 & 216 & 251 & 375 & 8.09 & 100 & 203 & 56 & 389 & 47.07 \\
\hline 19 & 59 & 0.66 & 1.99 & 109 & 5 & 0.81 & 0.46 & 127 & 1100 & 28.70 & 842 & 0.73 & 140 & 105 & 941 & 13.91 & 120 & 166 & 88 & 458 & 41.90 \\
\hline 20 & 31 & 0.11 & 0.81 & 60 & 2 & 0.29 & 0.20 & 109 & 184 & 28.76 & 285 & 1.06 & 174 & 165 & 351 & 16.92 & 24 & 117 & 63 & 145 & 29.10 \\
\hline 21 & 15 & 0.05 & 0.32 & 19 & 6 & 0.08 & 0.06 & 50 & 201 & 30.69 & 614 & 1.46 & 218 & 154 & 60 & 6.96 & 4 & 155 & 47 & 25 & 45.16 \\
\hline 22 & 34 & 0.67 & 1.72 & 103 & 3 & 0.66 & 0.63 & 89 & 712 & 26.15 & 314 & 1.47 & 237 & 212 & 2454 & 13.11 & 146 & 152 & 53 & 157 & 36.76 \\
\hline 23 & 16 & 0.32 & 4.42 & 186 & 2 & 0.07 & 0.07 & 131 & 1025 & 26.08 & 469 & 0.53 & 92 & 82 & 297 & 12.31 & 13 & 161 & 51 & 119 & 46.98 \\
\hline 24 & 28 & 0.11 & 1.24 & 48 & 9 & 0.38 & 0.06 & 80 & 659 & 27.78 & 290 & 1.03 & 184 & 161 & 308 & 17.49 & 18 & 84 & 67 & 138 & 31.34 \\
\hline 25 & 22 & 0.09 & 1.10 & 69 & 12 & 0.16 & 0.09 & 30 & 330 & 31.38 & 436 & 1.00 & 185 & 129 & 290 & 3.58 & 6 & 103 & 38 & 93 & 47.22 \\
\hline 26 & 18 & 0.12 & 0.59 & 114 & 3 & 0.11 & 0.11 & 103 & 301 & 25.26 & 344 & 1.00 & 281 & 400 & 1251 & 20.41 & 107 & 199 & 192 & 199 & 36.30 \\
\hline 27 & 20 & 0.08 & 0.35 & 39 & 5 & 0.17 & 0.08 & 51 & 217 & 35.16 & 295 & 1.97 & 253 & 182 & 302 & 7.87 & 9 & 96 & 127 & 87 & 40.29 \\
\hline 28 & 11 & 0.07 & 0.52 & 227 & 3 & 0.05 & 0.05 & 118 & 207 & 23.43 & 292 & 0.92 & 284 & 256 & 727 & 20.11 & 55 & 150 & 135 & 135 & 36.62 \\
\hline 29 & 17 & 0.89 & 2.65 & 98 & 4 & 0.78 & 0.55 & 143 & 662 & 21.39 & 368 & 0.72 & 185 & 335 & 372 & 12.05 & 30 & 192 & 94 & 174 & 48.98 \\
\hline 30 & 29 & 0.45 & 5.34 & 275 & 4 & 0.87 & 0.69 & 136 & 1458 & 21.16 & 202 & 0.62 & 65 & 110 & 421 & 6.19 & 23 & 79 & 13 & 109 & 47.79 \\
\hline Ø & 33 & 0.35 & 1.79 & 112 & 6.13 & 0.71 & 0.59 & 95 & 592 & 24.89 & 450 & 1.22 & 214 & 218 & 719 & 12.69 & 48 & 161 & 77 & 203 & 43.46 \\
\hline$\frac{\text { Av.sed. }}{\text { Av.shale }}$ & 0.29 & 0.27 & 0.46 & 0.63 & 1.52 & 0.37 & 1.96 & 0.61 & 0.82 & 1.21 & 2.57 & 1.31 & 2.07 & 2.72 & 1.71 & 1.83 & 3.68 & 4.02 & 1.54 & 2.13 & 0.72 \\
\hline$\frac{\text { Av.sed. }}{\text { Av.rock }}$ & 1.53 & 0.12 & 0.63 & 0.63 & 2.92 & 0.55 & 0.17 & 0.58 & 0.83 & 2.04 & 4.33 & 1.91 & 2.51 & 10.45 & 1.13 & 2.22 & 4.48 & 7.07 & 2.96 & 1.57 & 0.74 \\
\hline
\end{tabular}


Table 2. The contents of $\mathrm{Zr}$ and other elements in the Elahera gem-bearing sediments (see Fig. 2 for locations)

\begin{tabular}{|c|c|c|c|c|c|c|c|c|c|c|c|c|c|c|c|c|c|c|c|c|c|}
\hline $\begin{array}{l}\text { ELAHERA } \\
\text { sed. } \\
\text { sample }\end{array}$ & $\begin{array}{c}\mathrm{Li} \\
\mathrm{ppm}\end{array}$ & $\begin{array}{c}\mathrm{Na}_{2} \mathrm{O} \\
\%\end{array}$ & $\begin{array}{c}\mathrm{K}_{2} \mathrm{O} \\
\%\end{array}$ & $\begin{array}{l}\mathrm{Rb} \\
\mathrm{ppm}\end{array}$ & $\begin{array}{c}\mathrm{Be} \\
\mathrm{ppm}\end{array}$ & $\begin{array}{c}\mathrm{MgO} \\
\%\end{array}$ & $\begin{array}{c}\mathrm{CaO} \\
\%\end{array}$ & $\begin{array}{c}\mathrm{Sr} \\
\mathrm{ppm}\end{array}$ & $\begin{array}{l}\mathrm{Ba} \\
\mathrm{ppm}\end{array}$ & $\begin{array}{c}\mathrm{Al}_{2} \mathrm{O}_{3} \\
\%\end{array}$ & $\begin{array}{l}\mathrm{Zr} \\
\mathrm{ppm}\end{array}$ & $\begin{array}{c}\mathrm{TiO}_{2} \\
\%\end{array}$ & $\begin{array}{c}\mathrm{V} \\
\mathrm{ppm}\end{array}$ & $\begin{array}{l}\mathrm{Cr} \\
\mathrm{ppm}\end{array}$ & $\begin{array}{l}\mathrm{Mn} \\
\mathrm{ppm}\end{array}$ & $\begin{array}{c}\mathrm{Fe}_{2} \mathrm{O}_{3} \\
\%\end{array}$ & $\begin{array}{l}\text { Co } \\
\text { ppm }\end{array}$ & $\begin{array}{l}\mathrm{Ni} \\
\mathrm{ppm}\end{array}$ & $\begin{array}{l}\mathrm{Cu} \\
\mathrm{ppm}\end{array}$ & $\begin{array}{l}\mathrm{Zn} \\
\mathrm{ppm}\end{array}$ & $\begin{array}{c}\mathrm{SiO}_{2} \\
\%\end{array}$ \\
\hline 31 & 29 & 0.16 & 1.58 & 112 & 6 & 0.91 & 0.39 & 32 & 306 & 32.56 & 440 & 0.86 & 120 & 111 & 1506 & 10.02 & 29 & 107 & 34 & 82 & 40.53 \\
\hline 32 & 68 & 0.22 & 1.05 & 56 & 5 & 0.26 & 0.12 & 10 & 457 & 25.87 & 473 & 0.80 & 156 & 124 & 1865 & 12.66 & 58 & 84 & 36 & 89 & 43.06 \\
\hline 33 & 38 & 0.39 & 3.38 & 99 & 5 & 0.70 & 0.43 & 35 & 412 & 25.09 & 320 & 0.78 & 117 & 110 & 651 & 8.91 & 27 & 95 & 39 & 105 & 47.07 \\
\hline 34 & 46 & 0.24 & 2.49 & 111 & 5 & 1.14 & 0.31 & 47 & 336 & 25.41 & 142 & 0.68 & 148 & 133 & 567 & 13.37 & 36 & 99 & 38 & 160 & 42.78 \\
\hline 35 & 29 & 0.68 & 2.37 & 103 & 5 & 2.43 & 1.87 & 37 & 784 & 19.41 & 397 & 0.67 & 91 & 130 & 2749 & 7.78 & 45 & 105 & 22 & 90 & 49.20 \\
\hline 36 & 25 & 0.81 & 4.73 & 183 & 5 & 0.59 & 0.39 & 28 & 425 & 18.57 & 375 & 0.65 & 107 & 196 & 1332 & 11.20 & 34 & 120 & 32 & 180 & 49.11 \\
\hline 40 & 39 & 0.11 & 0.69 & 448 & 4 & 0.83 & 0.11 & 13 & 197 & 18.02 & 167 & 0.78 & 131 & 177 & 160 & 12.83 & 27 & 67 & 127 & 132 & n.a. \\
\hline 41 & 43 & 0.11 & 0.77 & 435 & 4 & 0.17 & 0.15 & 13 & 391 & 21.80 & 119 & 0.78 & 139 & 127 & 230 & 11.68 & 40 & 66 & 106 & 268 & n.a. \\
\hline 42 & 52 & 0.14 & 0.95 & 571 & 4 & 1.73 & 0.59 & 29 & 1078 & 21.67 & 128 & 0.72 & 130 & 115 & 1110 & 13.12 & 81 & 75 & 111 & 117 & n.a. \\
\hline 43 & 5 & 0.09 & 0.81 & 569 & 4 & 0.32 & 0.21 & 16 & 571 & 22.91 & 136 & 0.80 & 134 & 125 & 650 & 12.63 & 62 & 74 & 96 & 99 & n.a. \\
\hline 44 & 45 & 0.12 & 1.04 & 558 & 4 & 0.32 & 0.20 & 21 & 278 & 27.68 & 141 & 0.78 & 126 & 126 & 200 & 11.78 & 29 & 64 & 61 & 70 & 55.93 \\
\hline 45 & 45 & 0.14 & 1.10 & 269 & 4 & 0.36 & 0.29 & 30 & 394 & 29.93 & 112 & 0.65 & 124 & 99 & 290 & 11.88 & 36 & 55 & 81 & 209 & 53.67 \\
\hline 46 & 39 & 0.08 & 0.43 & 566 & 3 & 0.22 & 0.18 & 10 & 336 & 21.25 & 119 & 0.82 & 159 & 150 & 240 & 14.49 & 53 & 70 & 64 & 102 & 59.55 \\
\hline 47 & 44 & 0.12 & 0.95 & 536 & 3 & 1.00 & 0.13 & 19 & 259 & 22.99 & 132 & 0.78 & 129 & 106 & 250 & 11.76 & 49 & 69 & 58 & 79 & n.a. \\
\hline 48 & 46 & 0.09 & 0.71 & 544 & 4 & 0.32 & 0.15 & 14 & 462 & 24.20 & 106 & 0.82 & 143 & 164 & 400 & 13.54 & 48 & 74 & 135 & 193 & 54.78 \\
\hline 49 & 31 & 0.57 & 0.30 & 104 & 2 & 1.00 & 0.22 & 29 & 549 & 24.41 & 121 & 0.63 & 151 & 130 & 400 & 13.30 & 78 & 49 & 80 & 303 & n.a. \\
\hline 50 & 36 & 0.08 & 0.35 & 525 & 2 & 0.17 & 0.17 & 8 & 357 & 17.85 & 108 & 0.75 & 137 & 126 & 260 & 13.06 & 33 & 59 & 251 & 213 & n.a. \\
\hline 51 & 39 & 0.15 & 0.51 & 488 & 5 & 0.30 & 0.22 & 14 & 250 & 25.88 & 128 & 0.70 & 129 & 171 & 240 & 13.83 & 35 & 60 & 232 & 196 & n.a. \\
\hline 52 & 50 & 0.11 & 0.96 & 569 & 4 & 0.34 & 0.20 & 29 & 405 & 23.93 & 133 & 0.93 & 140 & 146 & 320 & 12.91 & 57 & 81 & 76 & 257 & n.a. \\
\hline 53 & 47 & 0.22 & 0.65 & 163 & 3 & 0.18 & 0.22 & 35 & 278 & 26.26 & 137 & 0.70 & 117 & 117 & 230 & 11.94 & 34 & 61 & 270 & 393 & n.a. \\
\hline 54 & 56 & 0.14 & 1.11 & 567 & 4 & 0.46 & 0.25 & 24 & 330 & 23.75 & 117 & 0.88 & 116 & 106 & 210 & 11.02 & 24 & 70 & 61 & 76 & n.a. \\
\hline$\varnothing$ & 41 & 0.23 & 1.28 & 360 & 4 & 0.65 & 0.33 & 23 & 422 & 23.78 & 193 & 0.76 & 130 & 133 & 660 & 12.08 & 44 & 76 & 96 & 163 & 49.57 \\
\hline$\frac{\text { Av.sed. }}{\text { Av.shale }}$ & 0.36 & 0.18 & 0.33 & 2.1 & 1 & 0.34 & 1.10 & 0.15 & 0.58 & 1.16 & 1.10 & 0.82 & 1.23 & 1.66 & 1.67 & 1.73 & 3.35 & 1.91 & 1.91 & 1.71 & 0.83 \\
\hline$\frac{\text { Av.sed. }}{\text { Av.rock }}$ & 1.40 & 0.13 & 0.35 & 5.2 & 3 & 0.22 & 0.04 & 0.17 & 0.53 & 2.13 & 1.25 & 1.62 & 1.33 & 14.15 & 0.53 & 2.74 & 0.77 & 1.79 & 8.76 & 0.98 & 0.91 \\
\hline ample no. 4 & $-54, d$ & ta adop & ed & Henn & 983) & & & & & & & & & & & & & & & & \\
\hline
\end{tabular}


Table 3. The contents of $\mathrm{Zr}$ and other elements in the rocks of the Ratnapura gem field

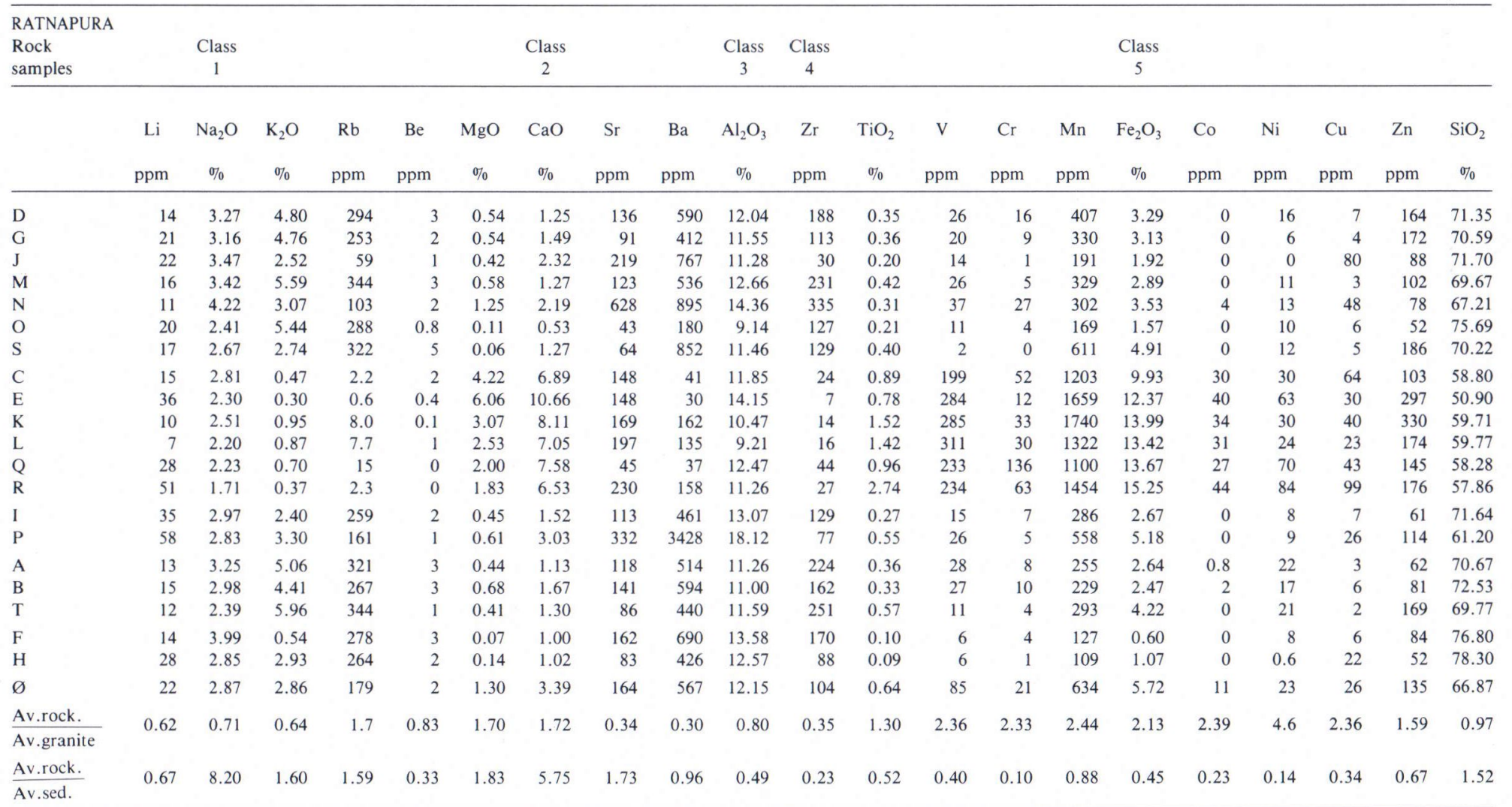

D, G, J, M, N, O, S, acid charnockite. C, E, K, L, Q, R, basic charnockite. I, P, intermedate charnockite. A, B, T, biotite gneiss. F, H, qtz. fsp.gneiss 
Table 4. The contents of $\mathrm{Zr}$ and other elements in the rocks of the Elahera gem field

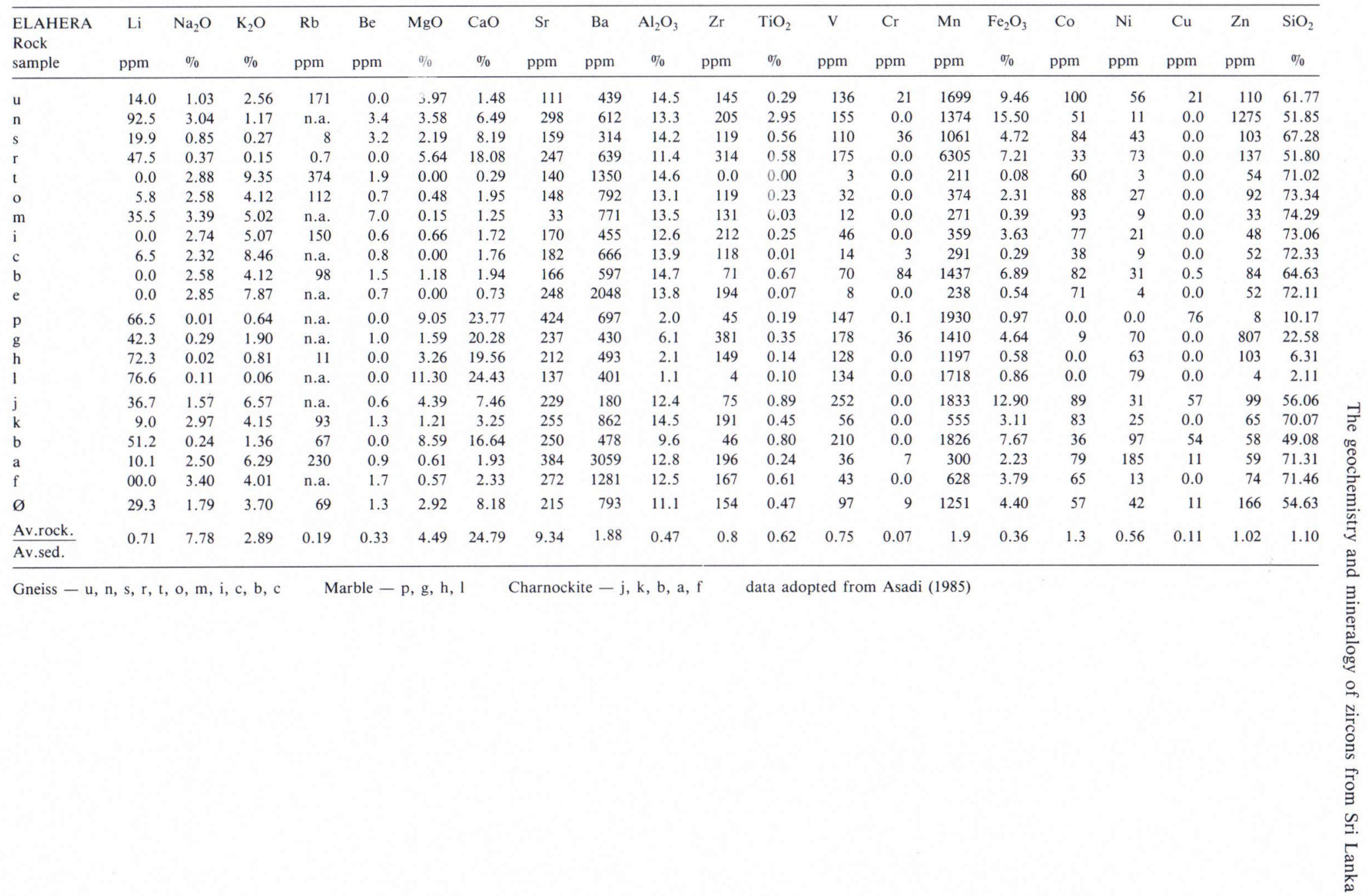




\section{CLASS I}

Ratnapura

- Sediment

$\triangle$ Probable source rocks

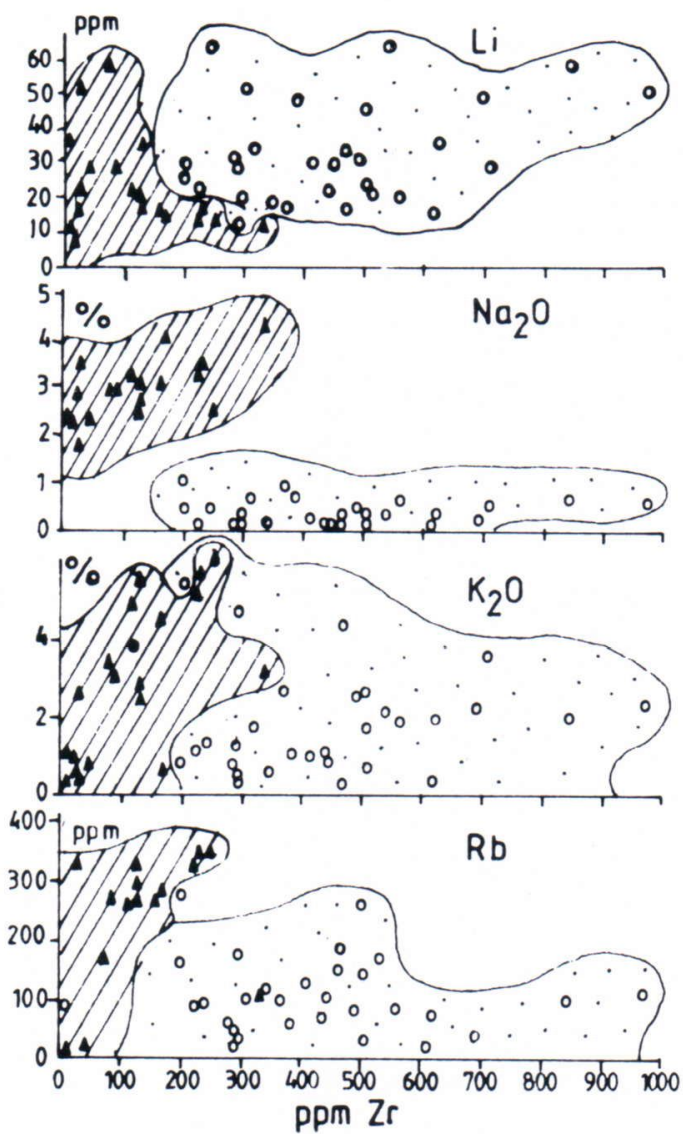

Elahera

- Sediment

- Probable source rocks
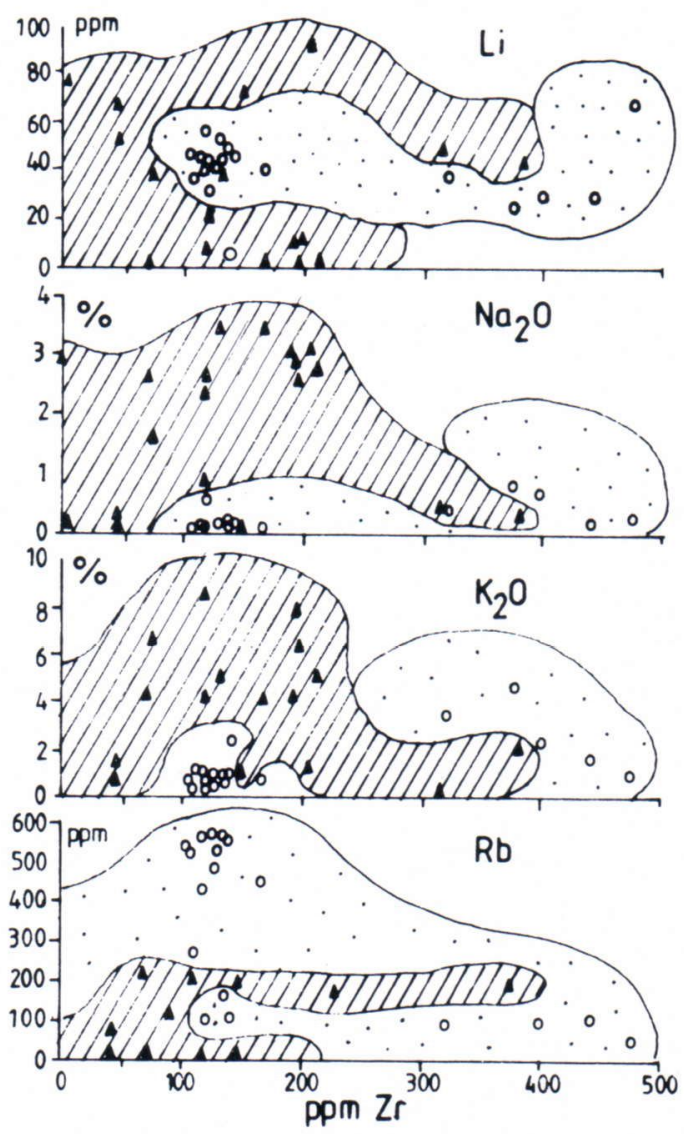

Fig. 3. Variation in $\mathrm{Zr}$ versus class 1 elements in sediments and rocks.

on each grain were analysed, taking great care to avoid inclusions and tiny voids.

In zoned zircons, planes cut normal to the c-axes were selected, and three points in each zone were analysed.

Precleaned zircon crystals were irradiated with thermal neutrons for six hours in the TRIGA reactor of Mainz University, West Germany, using a $7.10^{11} \mathrm{n} \mathrm{cm}^{-2} \mathrm{sec}^{-1}$, neutron flux. The grain weights were in the range $0.3-0.5 \mathrm{~g}$. Since the irradiation was not followed by a cooling period, the zircon crystals were transferred immediately to a $\mathrm{Ge}(\mathrm{Li})$ detector where the intensities of the X-ray spectra were determined. For details of the method, see Wänke et al. (1977) and Blum (1977). The samples were irradiated for 


\section{CLASS II}

\section{Ratnapura}

$$
\text { - Sediment }
$$
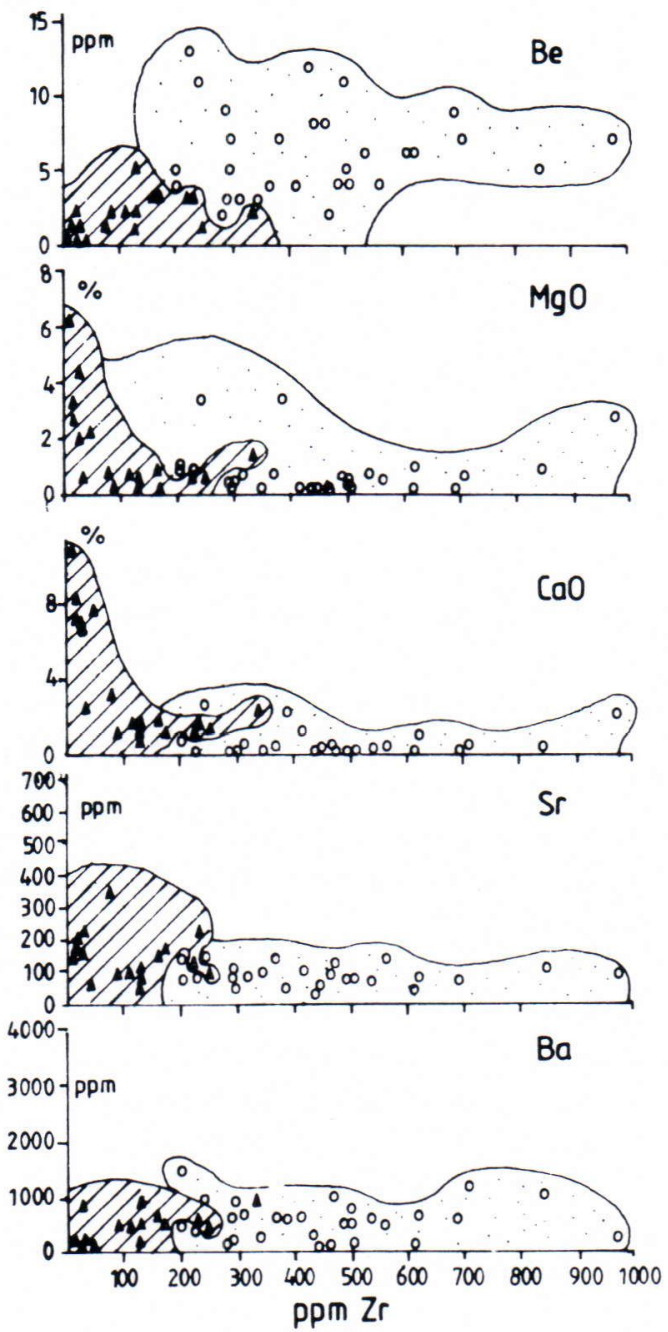

\section{Elahero}

- Sediment
- Probable source rocks
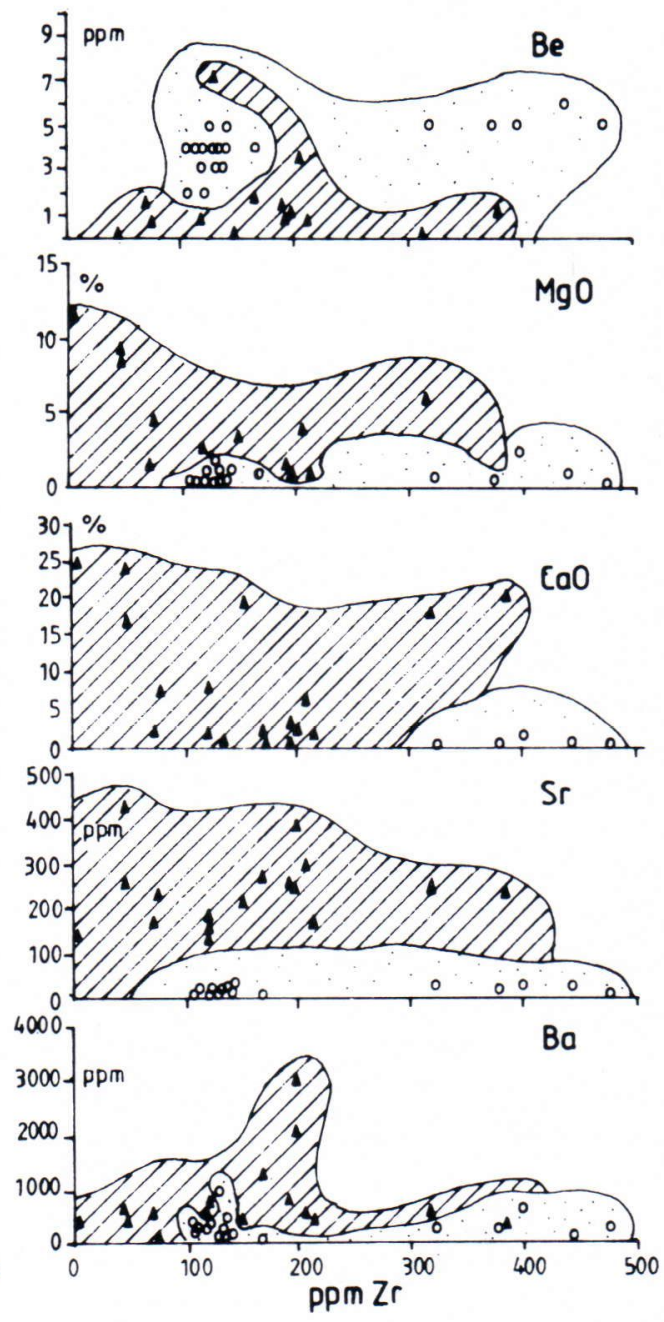

Fig. 4. Variation in $\mathrm{Zr}$ versus class 2 elements in sediments and rocks.

exactly the same length of time and in the same position in the reactor.

Element standards were included to check the specific activities of the elements determined in the unknown samples. The zonation in the zircon crystals was studied with scanning electron microscopy.

\section{Results and discussion}

The geochemistry of $\mathrm{Zr}$ in gem-bearing sediments and rocks

Table 1-4 shows the contents of $\mathrm{Zr}$ and other elements in the sediments and rocks of the two main gem fields of Sri Lanka, Ratnapura 


\section{CLASSIII}

\section{Ratnapura}

- Sediment

- Probable source rock

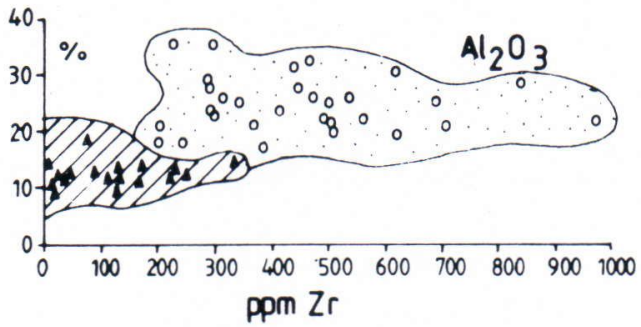

\section{Elahera}

- Sediment

- Probable source rock

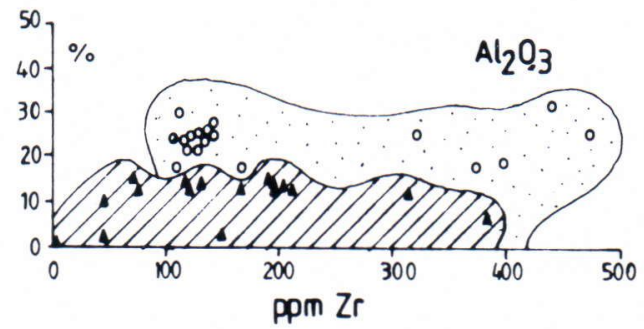

Fig. 5. Variation in $\mathrm{Zr}$ versus class 3 elements in sediments and rocks.

and Elahera. The average $\mathrm{Zr}$ content of the Ratnapura gem sediments is $450 \mathrm{ppm}$ as against $193 \mathrm{ppm}$ in the Elahera gem field. The enrichment factors denoted as average sediment/average shale and average sediment/average rock for the Ratnapura sediments are 2.57 and 4.33, respectively. At Elahera they are 1.10 and 1.85, respectively, indicating a marked enrichment of $\mathrm{Zr}$ in the Ratnapura gem-bearing sediments. The difference in the geochemical behaviour of $\mathrm{Zr}$ in the probable source rocks and gem-bearing sediments is best illustrated by plots showing the variation of $\mathrm{Zr}$ versus the other elements. These elements could be grouped into four classes as follows:

Class 1: Li, Na, K, Rb

Class 2: $\mathrm{Be}, \mathrm{Mg}, \mathrm{Ca}, \mathrm{Sr}, \mathrm{Ba}$

Class 3: $\mathrm{Al}$

Class 4: Ti, V, Cr, Mn, Fe, Co, Ni, Cu, Zn

Figure 3 gives the variation diagrams for $\mathrm{Zr}$ versus the class 1 elements $\mathrm{Li}, \mathrm{Na}, \mathrm{K}$ and $\mathrm{Rb}$ for the Ratnapura and Elahera gem fields. The clusters for the sediments and the probable source rocks for these alkali elements are clearly demarked, particularly for the Ratnapura gem field. In general, the element to $\mathrm{Zr}$ ratio is much greater in the rocks owing to their smaller $\mathrm{Zr}$ concentration.
Figure 4 shows the variation diagram for $\mathrm{Zr}$ versus the class 2 elements $\mathrm{Be}, \mathrm{Mg}, \mathrm{Ca}, \mathrm{Sr}$ and $\mathrm{Ba}$. As with the class 1 elements, there is a marked difference in trends, $\mathrm{Mg}, \mathrm{Ca}$ and $\mathrm{Sr}$ in particular showing that the behaviour of these elements with $\mathrm{Zr}$ is not the same in the sediments as in the rocks. The class 3 element $\mathrm{Al}$ shows a positive variation with $\mathrm{Zr}$ in both sediments and rocks (Fig. 5).

The transition elements, all in class 4 , show similar geochemical behaviour with $\mathrm{Zr}$. In the Ratnapura sediments in particular, these elements exhibit an apparently negative correlation in the probable source rocks, whereas in the sediments the correlation is positive. The Elahera trends, however, are less conspicuous than the Ratnapura ones (Fig. 6).

\section{Electron microprobe analysis of zircons}

A total of 49 zircon samples comprising 21 green, 11 violet, 12 yellow and five rose varieties were analysed by electron microprobe. At a rate of three points per sample, a total of 147 points were analysed for $\mathrm{Si}, \mathrm{Fe}, \mathrm{Zr}, \mathrm{Hf}$, Th and U. As shown in Table 5, the four colour varieties have different concentrations of the elements studied. The green zircons are relatively enriched in $\mathrm{Hf}$, 


\section{CLASS N}

Rimapure

- Sediment

- Probable source rock

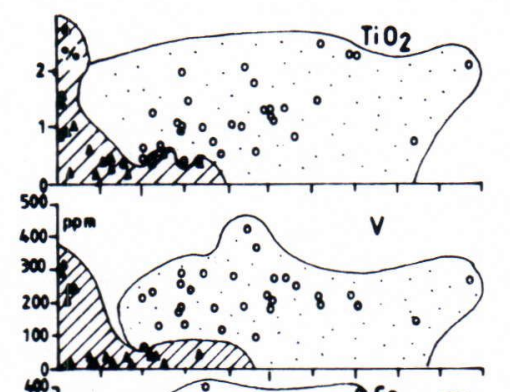

\section{Elohera}

- Sedinent

- Probable source rock
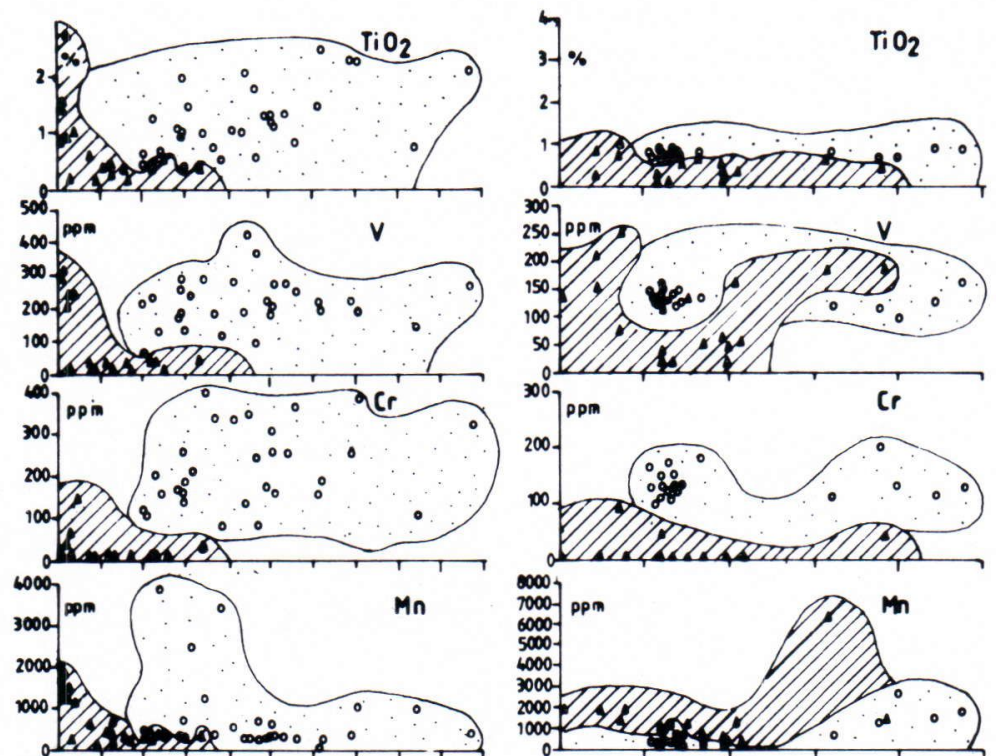

8000
7000
5000
5000
2000
2000
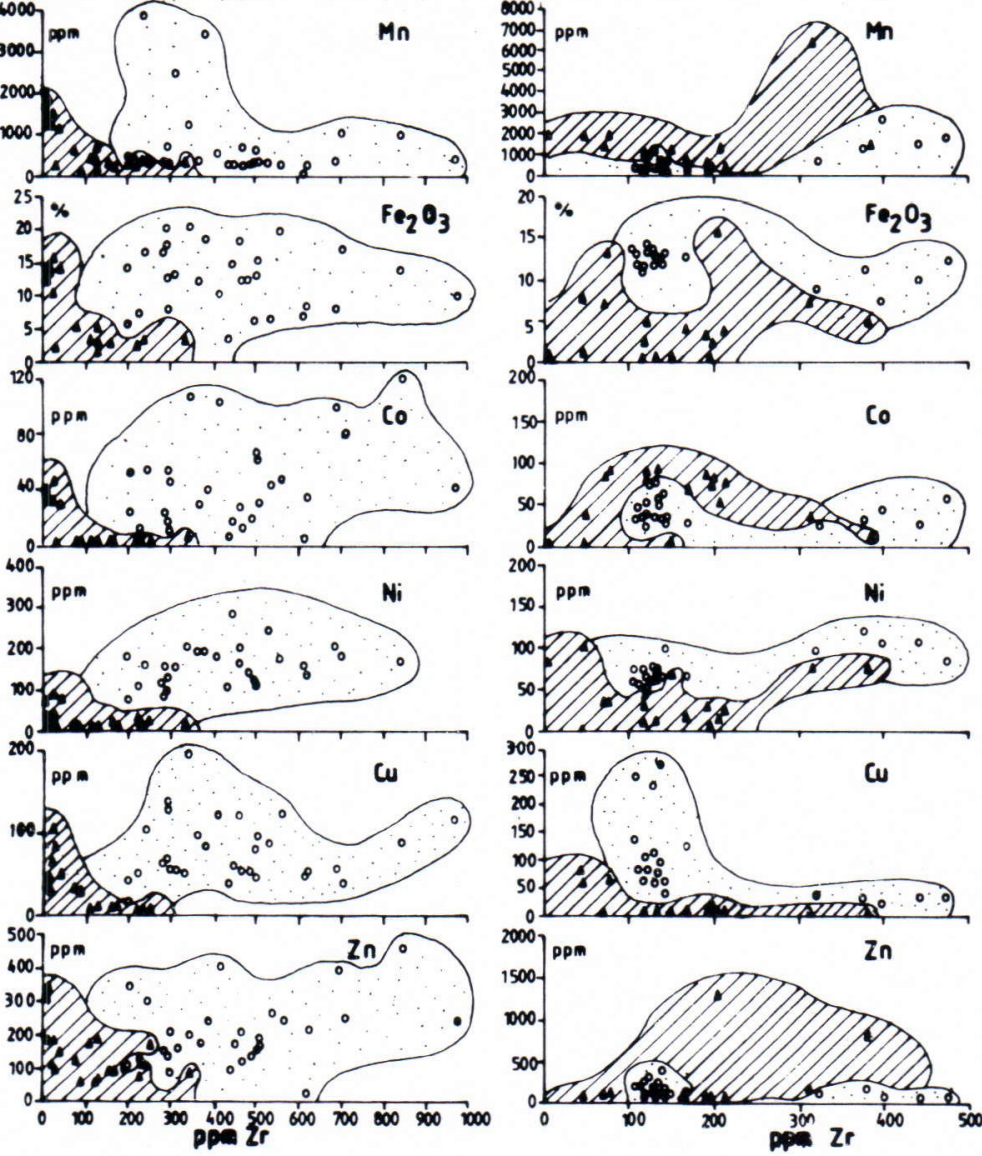

Fig. 6. Variation in $\mathrm{Zr}$ versus class 4 elements in sediments and rocks. 
Table 5. Elemental composition of the four varieties of 49 zircons from Sri Lanka

\begin{tabular}{lcccccccc}
\hline & $\mathrm{Si} \%$ & $\mathrm{Fe} \%$ & $\mathrm{Zr} \%$ & $\mathrm{Hf} \%$ & $\mathrm{Th} \%$ & $\mathrm{U} \%$ & $\mathrm{U} / \mathrm{Fe}$ & $\mathrm{Zr} / \mathrm{Hf}$ \\
\hline Green & 15.87 & 0.067 & 47.69 & 1.436 & 0.112 & 0.410 & 6.139 & 33.21 \\
Violet & 16.02 & 0.017 & 48.64 & 1.007 & 0.084 & 0.113 & 6.653 & 48.31 \\
Yellow & 15.67 & 0.021 & 48.25 & 1.193 & 0.074 & 0.136 & 6.476 & 40.44 \\
Rose & 15.82 & 0.025 & 48.64 & 1.084 & 0.060 & 0.119 & 4.760 & 44.87 \\
& $\mathrm{Zr} / \mathrm{Th}$ & $\mathrm{Zr} / \mathrm{U}$ & $\mathrm{Th} / \mathrm{U}$ & $\mathrm{Hf} / \mathrm{Th}$ & $\mathrm{Hf} / \mathrm{U}$ & $\mathrm{Zr} / \mathrm{Si}$ & $\mathrm{Zr} / \mathrm{Fe}$ & $\mathrm{Th} / \mathrm{Fe}$ \\
Green & 426.7 & 116.5 & 0.273 & 12.84 & 3.51 & 3.00 & 751 & 1.672 \\
Violet & 579.1 & 430.1 & 0.742 & 11.99 & 8.90 & 3.04 & 2861 & 4.941 \\
Yellow & 652.0 & 354.8 & 0.574 & 16.12 & 8.77 & 3.08 & 2298 & 3.524 \\
Rose & 810.6 & 408.7 & 0.504 & 18.07 & 9.11 & 3.07 & 1946 & 2.400 \\
\hline
\end{tabular}
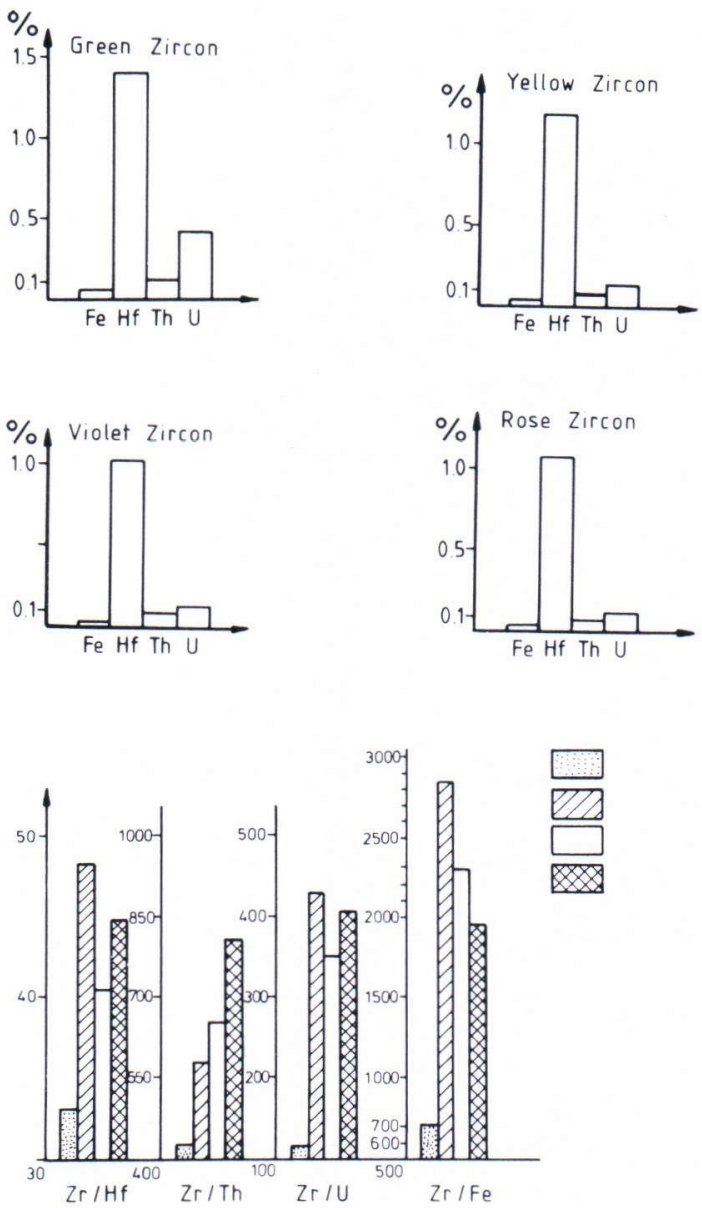

Fig. 7. Histograms showing the Fe, Hf, Th and $\mathrm{U}$ contents and their ratios to $\mathrm{Zr}$ in the four varieties of zircons.

Th and $\mathrm{U}$, whereas the rose and violet varieties show low $\mathrm{Hf}$, Th and $\mathrm{U}$ concentrations. The average $\mathrm{Zr} / \mathrm{Hf}$ ratio of terrestrial rocks is ap- proximately 40 (Brooks 1970), which is known to increase with differentiation, increasing alkalinity, volatile content and silica undersaturation (Pavlenko et al. 1957). As shown in Table 5 and Fig. 7, the green variety has the lowest $\mathrm{Zr} / \mathrm{Hf}$ ratio of 33 , and the violet type the highest ratio

Table 6. The REE contents of some zircons from Sri Lanka

\begin{tabular}{lccccc}
\hline Sample* & 1 & 2 & 3 & 4 & 5 \\
\hline $\mathrm{Ce}$ & - & - & - & - & - \\
$\mathrm{Pr}$ & - & - & - & - & - \\
$\mathrm{Nd}$ & - & - & - & - & - \\
$\mathrm{Sm}$ & 0.25 & 1.12 & 1.34 & - & - \\
$\mathrm{Eu}$ & 0.08 & 0.27 & 0.35 & 0.51 & 0.48 \\
$\mathrm{Gd}$ & - & - & - & - & - \\
$\mathrm{Tb}$ & 0.16 & 0.55 & 0.63 & 2.20 & 1.80 \\
$\mathrm{Dy}$ & 1.42 & 6.68 & 5.14 & 19.40 & 17.78 \\
$\mathrm{Ho}$ & 0.50 & 2.42 & 1.92 & 8.30 & 5.30 \\
$\mathrm{Er}$ & 2.40 & 9.71 & 7.14 & - & - \\
$\mathrm{Tm}$ & - & - & - & - & - \\
$\mathrm{Yb}$ & 3.58 & 10.74 & 9.33 & 74.00 & 34.58 \\
$\mathrm{Lu}$ & 0.70 & 2.05 & 1.41 & 16.00 & 6.11 \\
$\mathrm{La}$ & - & - & - & 0.40 & 0.37 \\
$\mathrm{I} \mathrm{REE}$ & 9.09 & 33.54 & 27.26 & 120.81 & 45.42 \\
$\mathrm{Sc}$ & 35.04 & 90.78 & 91.03 & 11.60 & 18.12 \\
$\mathrm{Mn}$ & 0.41 & 0.28 & 0.49 & 4.00 & 6.06 \\
$\mathrm{Ta}$ & 2.11 & 2.32 & 2.05 & 1.00 & 2.12 \\
$\mathrm{U}$ & 6.68 & 18.50 & 14.32 & 2410.00 & 1168.61 \\
$\mathrm{Th}$ & 12.18 & 8.50 & 7.43 & 425.00 & 761.00 \\
$\mathrm{Hf}$ & $1.14 \%$ & $0.90 \%$ & $1.13 \%$ & $2.00 \%$ & 1.76 \\
$\mathrm{Co}$ & - & - & 0.34 & - & - \\
$\mathrm{W}$ & - & 0.91 & 2.76 & - & - \\
$\mathrm{Ga}$ & - & 0.25 & - & - & 6.9 \\
$\mathrm{Ir}$ & - & - & 0.85 & - & - \\
$\mathrm{Fe}$ & $0.002 \%$ & $0.002 \%$ & $0.002 \%$ & $0.01 \%$ & $0.02 \%$ \\
$\mathrm{Na}$ & - & - & - & 6.00 & 19.00 \\
$\mathrm{~K}$ & - & - & - & 15.00 & - \\
$\mathrm{Zr}$ & $\mathrm{n} . \mathrm{a}$. & $\mathrm{n} . \mathrm{a}$. & $\mathrm{n} . \mathrm{a}$. & $46.90 \%$ & $47.25 \%$ \\
\hline & & & & &
\end{tabular}

* content in ppm unless marked otherwise n.a. - not analysed

1, 2, 3 - Analyst Schwarz, D

4, 5 - Analyst Rupasinghe, M.S. 

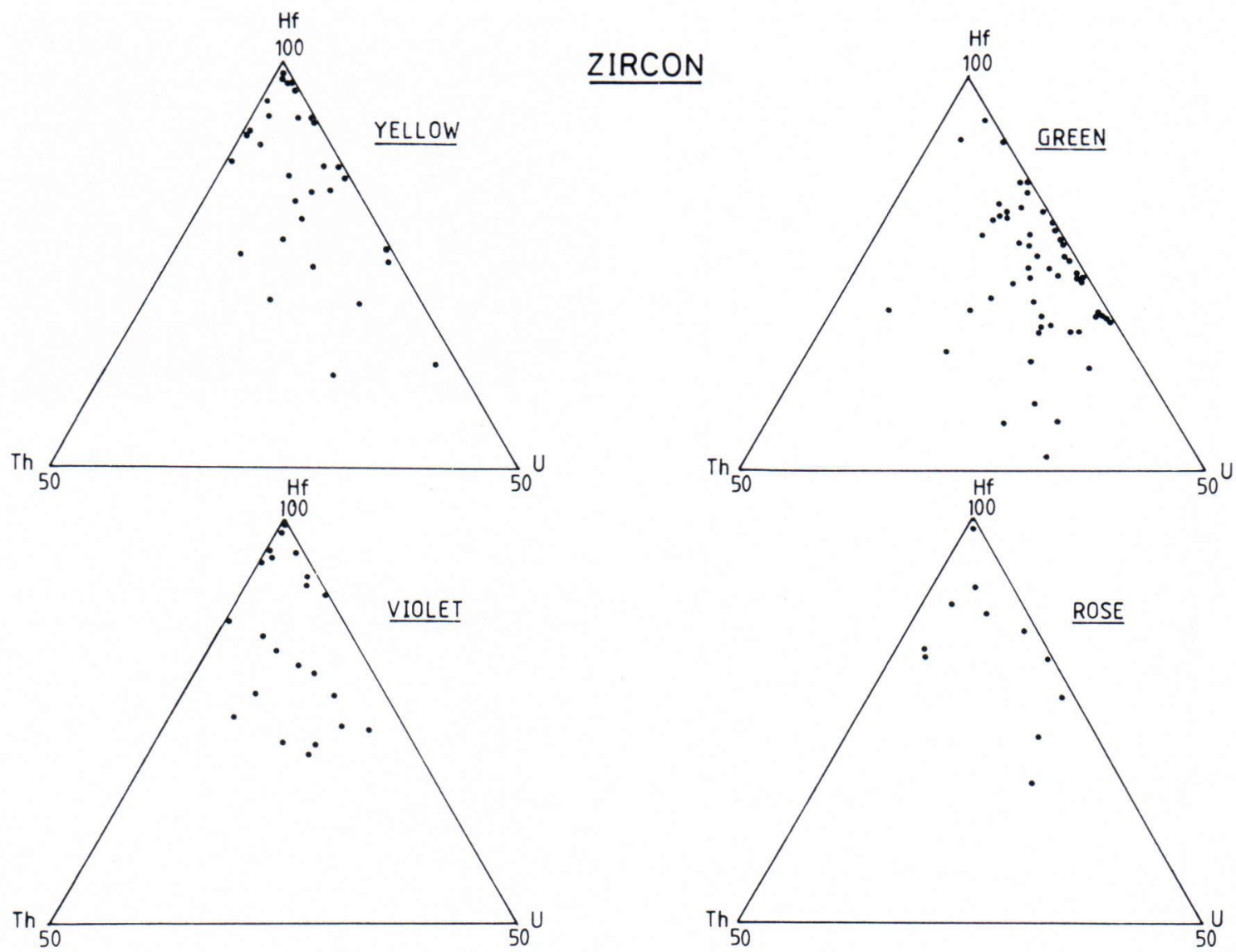

Fig. 8. Hf - Th $-U$ ternary diagrams for the four varieties of zircons.

of 48. Further, the green zircons exhibit the lowest $\mathrm{Zr} / \mathrm{Th}$ and $\mathrm{Zr} / \mathrm{U}$ ratios in contrast to the rose and violet types. A noteworthy feature of the green zircons is their low $\mathrm{Hf} / \mathrm{U}$ ratio of 3.51 as against 9.11 in the rose type, a decrease by a factor of three. The variations in $\mathrm{Th}, \mathrm{U}$ and $\mathrm{Hf}$ are illustrated in the ternary diagrams (Fig. 8).

\section{REE and other trace elements}

Table 6 shows the REE contents of some Sri Lanka zircons. As expected there is a general preference for HREE (Eu-Lu) and the total REE content varies from 9.09 to 120.81 . Figure 9 illustrates the chondrite-normalized REE plots for the samples studied. Work by Nagasawa
(1970), Puchelt and Enmermann (1976), and Irving and Frey (1978) have shown that the same mineral - whether zircon, garnet or apatite - from different rock types exhibits different mineral/chondrite REE patterns. The differences in the REE content of a specific mineral reflect differences in the bulk rock REE content and variations in REE partition coefficients as a function of pressure, temperature and composition (Murali et al. 1983). Accordingly, the similarity between REE plots of the zircons in this study indicates a common source for the gem-bearing sediments.

On account of its similar ionic radius, co-ordination number and electronegativity, scandium, $\mathrm{Sc}^{3+}$ tends to substitute for $\mathrm{Zr}^{4+}$ and $\mathrm{Hf}^{4+}$ in 


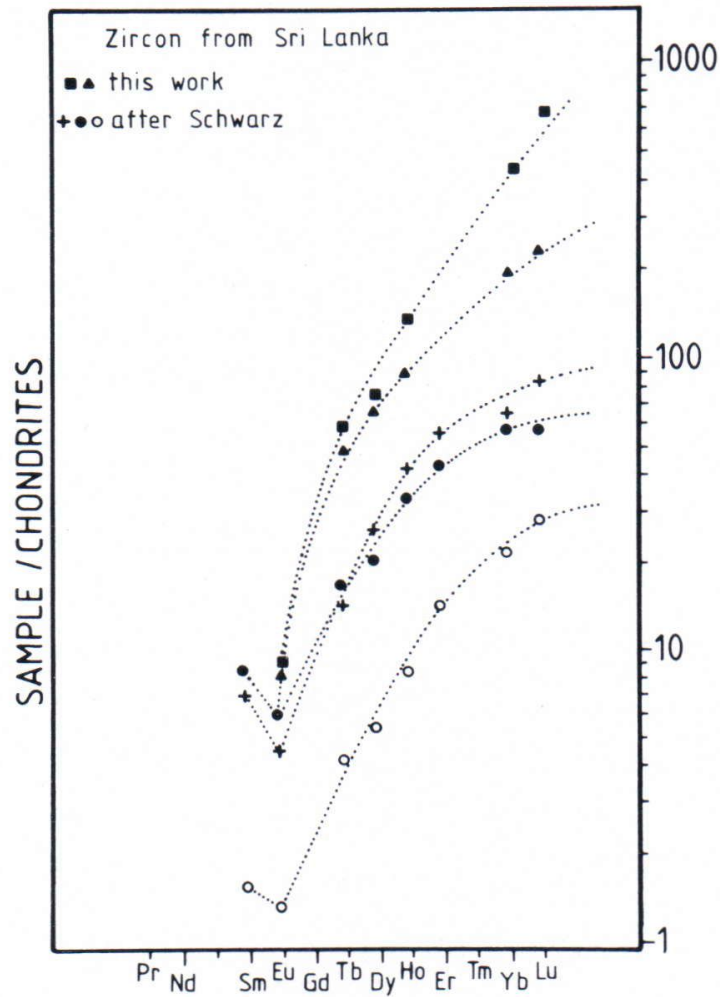

Fig. 9. Chondrite-normalized rare earth elements plots for some zircons in Sri Lanka.

Zr- and Hf-bearing minerals (Vlasov 1966). The Sc content of the zircons studied varies from 18 to 91 . Zircon samples 4 and 5 (Table 5) display a very high concentration of $\mathrm{Th}, \mathrm{U}$ and $\mathrm{Hf}$ and, in this respect, it is of interest to note that some of the placer monazites of Sri Lanka are among the world's most thorium-rich monazites (Overstreet 1967; Rupasinghe et al. 1984). Some granitic bodies of Sri Lanka are also known to be rich in uranium.

\section{Zoned zircons}

A total of seven zoned zircons (Fig. 10) were selected for electron microprobe study. Approximately three points per zone were analysed in a total of 159 points. Table 7 shows the correla-

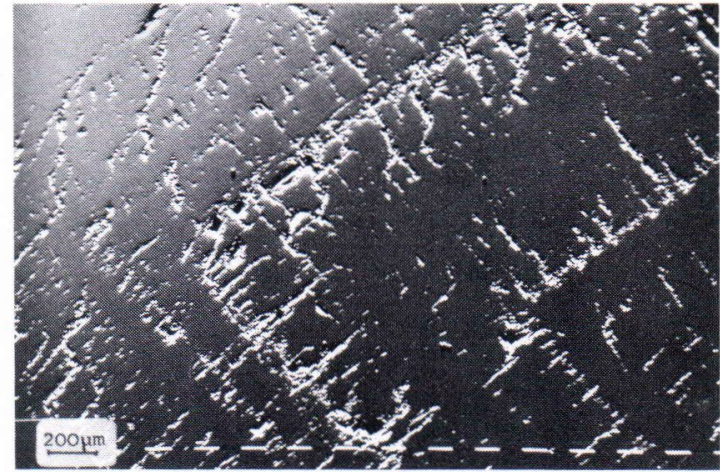

Fig. 10. Electron microscope image of zoned zircon from Sri Lanka.

Table 7. The correlation matrix for elements in zoned and ordinary zircons. Zircon from Sri Lanka, correlation coefficients

\begin{tabular}{lrrrrrr}
\hline & Si & Fe & Zr & Hf & Th & U \\
\hline $\mathrm{Si}$ & 1.000 & & & & & \\
$\mathrm{Fe}$ & 0.287 & 1.000 & & & & \\
$\mathrm{Zr}$ & -0.308 & -0.329 & 1.000 & & & \\
$\mathrm{Hf}$ & -0.128 & -0.024 & -0.171 & 1.000 & & \\
$\mathrm{Th}$ & -0.007 & 0.017 & 0.010 & -0.068 & 1.000 & \\
$\mathrm{U}$ & -0.049 & -0.041 & -0.166 & 0.455 & 0.040 & 1.000 \\
\hline
\end{tabular}

tion matrix for the zoned and normal zircons, there being no significant correlation between any of the element pairs. Figures 11 and 12 illustrate the surface distribution of the elements and their ratios. Note that, although the elements studied exhibit periodic highs and lows of element concentrations within a zone, there is no strong increase or decrease towards the core of the zircon.

\section{Conclusions}

Zircons found ubiquitously in the gem-bearing sediments of Sri Lanka are relatively rich in $\mathrm{Th}$, $\mathrm{U}$ and $\mathrm{Hf}$. The green, yellow, violet and rose varieties analysed had varying trace element concentrations, with the green zircons having the highest Th, U and Hf contents. Geochemical 

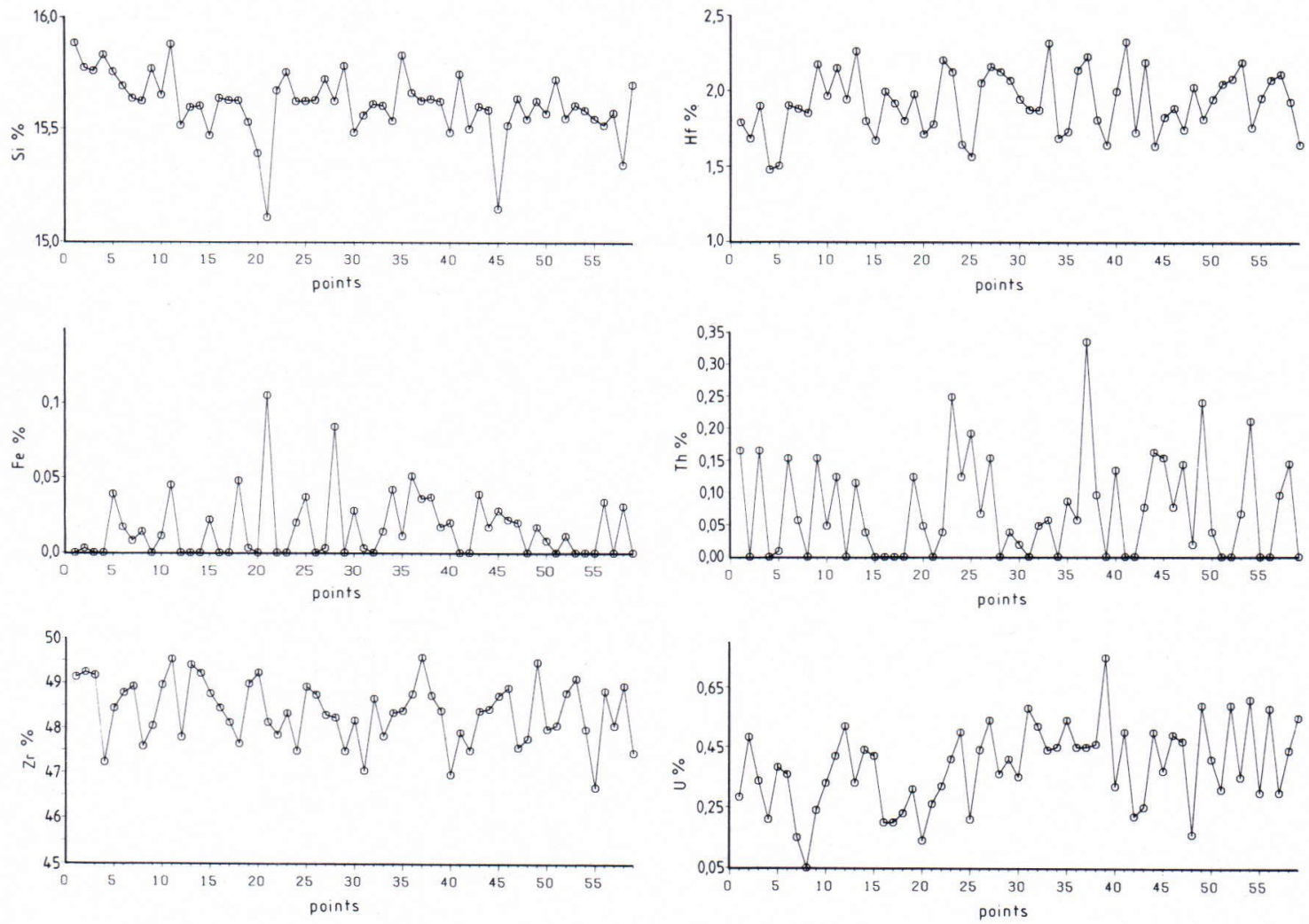

Fig. 11. Elemental variations in zoned zircons.

studies reveal markedly different geochemical behaviour of $\mathrm{Zr}$ with respect to other elements in the gem-bearing sediments and in the probable source rocks. In the Ratnapura gem field the $\mathrm{Zr}$ contents of the gem sediments are enriched by a factor of four as against the rocks of the gem fields. In the Elahera region, however, this factor is approximately two.

Chondrite - normalized REE plots for selected zircons show a similar pattern with enrichments of the heavy rare-earth elements.
Acknowledgements. This work forms part of the doctoral research work of M. S. Rupasinghe and he gratefully acknowledges the grant awarded him by the Otto Benecke Stiftung, West Germany. C. B. Dissanayake acknowledges with thanks the post-doctoral research grant awarded him by the Alexander von Humboldt Foundation of West Germany. Special gratitude is due to professor J. Pense and Dr. A. Benerjee. The authors also thank Mr. J. Mallay and A. Senaratne for their assistance. 

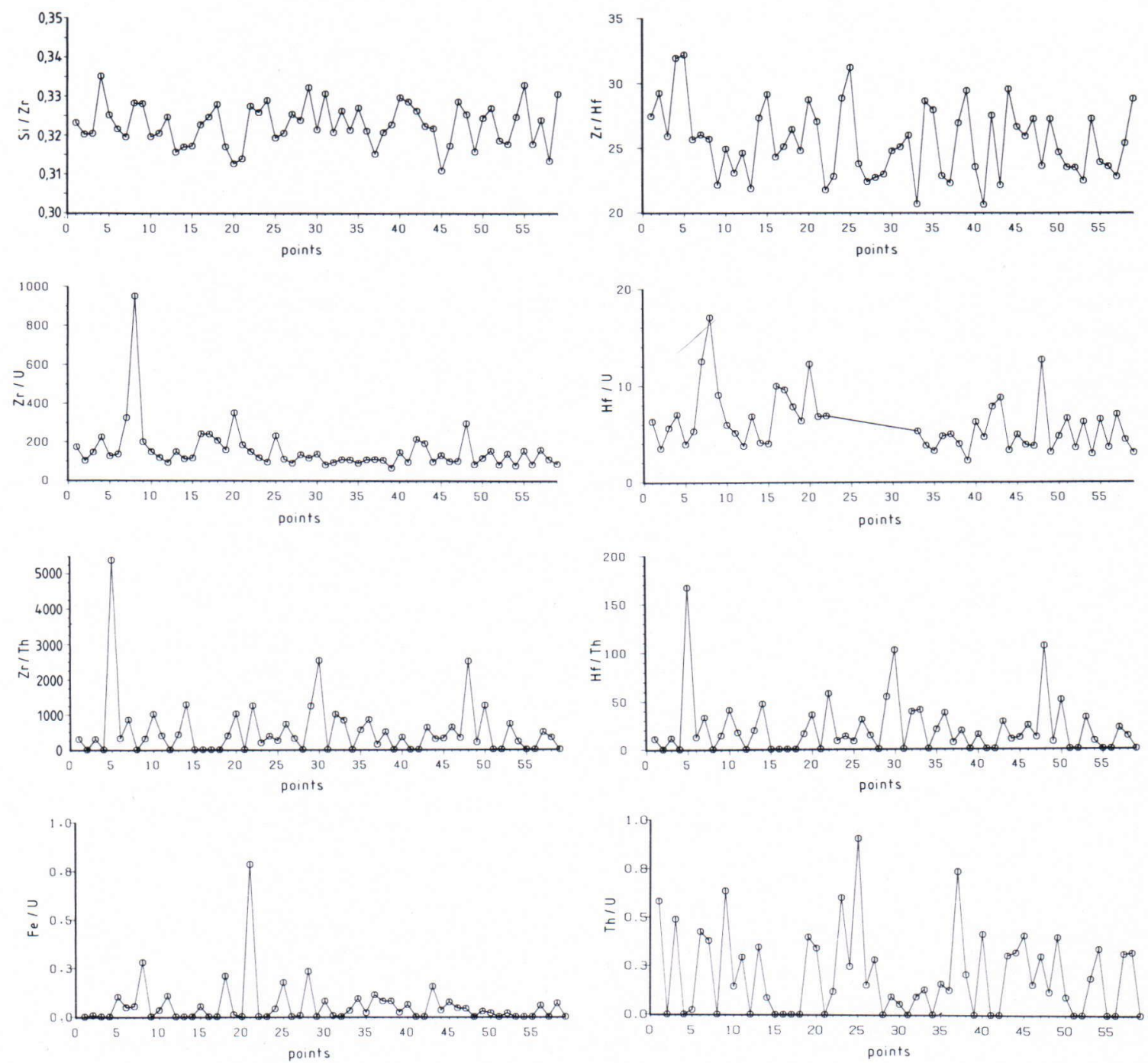

Fig. 12. Variation in elemental ratios in zoned zircons.

\section{References}

Asadi, B., 1985. Geochemische und petrographische Untersuchungen an Edelstein-führenden gesteinen. Unpubl. Diplomthesis, Univ. Mainz.

Brooks, C. K., 1970. The concentrations of zirconium and Hafnium in some igneous and metamorphic rocks and minerals. Geochim. Cosmochim. Acta 34, 411-416.

Cooray, P. G., 1978. Geology of Sri Lanka. In Nutalaya, P. (Ed.) $3^{\text {rd }}$ Regional Conf. Geology and Mineral Resources of Southeast Asia, Bangkok, 701-710.
Exley, R. A., 1980. Microprobe studies of REE-rich accessory minerals. Implications for Skye granite petrogenesis and REE mobility in hydrothermal systems. Earth Planet Sci. Lett. 48, 97-110.

Fleischer, M. \& Altschuler, Z. S., 1969. The relationship of the rare-earth composition of minerals to geological environment. Geochim. Cosmochim. Acta. 33, 725-732.

Henn, U., 1983. Die Minerale der Edelsteinlagerstätte bei Elahera, Sri Lanka. Ein sedimentologiseher, mineralogischer und geochemischer Beitrag. Unpubl. Diplomthesis, Univ. Mainz. 
Irving, A. J. \& Frey, F. A., 1978. Distribution of trace elements between garnet megacryst and host volcanic liquids of kimberlitic to rhyolitic compositions. Geochim. Cosmochim. Acta 42, 743-771.

Murahi, A. V.; Parthasarathy, R.; Mahadevan, T. M. \& Sankar Das, M., 1983. Trace element charnockites, REE patterns and partition coefficients of zircons from different geological environments - A case study on Indian zircons. Geochim. Cosmochim. Acta 47, 2047-2057.

Nagasawa, H., 1970. Rare-earth concentrations in zircons and apatites and their host dacites and granites. Earth Planet Sci. Lett. 9, 359-364.

Overstreet, W. S., 1967. The geologic occurrence of monazite. U.S. Geol. Surv., Prof. Paper 530, 294 p.

Pavlenko, A. S.; Vainshtein, E. E. \& Shevaleeskii, C. D., 1957. On the hafnium/zirconium ratio in zircon of igneous and metasomatic rocks. Geochim. 5, 411-430.

Puchelt, H. \& Emmermann, R., 1976. Bearing of rare-earth pattern of apatites from igneous and metamorphic rocks. Earth Planet Sci. Lett. 31, 279-286.

Rupasinghe, M. S.; Gocht, W. \& Dissanayake, C. B., 1984. The genesis of thorium-rich monazite in Sri Lanka. I. Nat. Sci. Gouncil Sri Lanka (In Press).

Silva, K. K. M. W., 1976. Some geological aspects of the Elahera gem field, Sri Lanka. Abst. Sri Lanka. Ass. Adv. Sci, 32nd Sess.

Schwarz, D., 1981. Chemismus and Fluorenzverhalten von Diamant- Imitation. Dissertation, Univ. Mainz.

Vlasov, K. A., 1966. Geochemistry and mineralogy of rare elements and genetic types of their deposits. Israel Programme for Scientific Translation Ltd.

Wadia, D. N. \& Fernando, C. J. D., 1945. Gems and semiprecious stones of Sri Lanka. Ceylon Dept. Miner. Res., Prof. Paper 2, 13-44.

Manuscript received January 18, 1985 